\title{
ANALISIS PERBANDINGAN PERSEPSI PELANGGAN TERHADAP BAURAN PEMASARAN KOPI JANJI JIWA DAN KOPI KENANGAN
}

\section{Ivan Christian, Jesslyn Kartawidjaja}

Universitas Katolik Parahyangan (UNPAR) Bandung Jawa Barat, Indonesia

Email: ivanchristian.sh@gmail.com, jesslyn.kartawidjaja@gmail.com

\begin{abstract}
Abstrak
Banyaknya kedai kopi di Kota Bandung membuat persaingan antar Kedai Kopi semakin ketat. Karena itu, penerapan bauran pemasaran yang tepat akan sangat berpengaruh terhadap minat pelanggan dalam memilih Kedai Kopi. Kopi Janji Jiwa Braga merupakan salah satu kedai kopi terlaris di Kota Bandung. Namun seiring didirikannya Kopi kenangan Braga, Kopi Janji Jiwa Braga memiliki pesaing langsung. Penelitian ini bertujuan untuk mengetahui perbandingan persepsi pelanggan terhadap bauran pemasaran di Kopi Janji Jiwa Braga dan Kopi Kenangan Braga. Bauran pemasaran yang diteliti meliputi 7 elemen dan 29 indikator bauran pemasaran. Metode yang digunakan dalam penelitian ini adalah metode deskriptif. Populasi dari penelitian ini adalah pelanggan yang pernah mengunjungi Kopi Janji Jiwa Braga dan Kopi Kenangan Braga. Sampel yang digunakan sebanyak 122 orang. Teknik pengumpulan data yang dipakai adalah observasi, wawancara, dan kuesioner. Teknik analisis data yang digunakan yaitu deskriptif dan uji beda Mann Whitney. Hasil penelitian menunjukkan bahwa persepsi pelanggan terhadap bauran pemasaran Kopi Janji Jiwa Braga dan Kopi Kenangan Braga adalah positif. Persepsi pelanggan terhadap 7 elemen bauran pemasaran Kopi janji Jiwa Braga dan Kopi Kenangan Braga adalah positif. Persepsi pelanggan terhadap 29 indikator bauran pemasaran Kopi Janji Jiwa Braga dan Kopi Kenangan Braga adalah setuju kecuali indikator keunikan dan pencahayaan Kopi Kenangan Braga yang hasilnya cukup setuju. Dari 29 indikator persepsi pelanggan terhadap bauran pemasaran Kopi Janji Jiwa Braga dan Kopi Kenangan Braga, 12 indikator tidak berbeda sedangkan 17 indikator berbeda.
\end{abstract}

Kata Kunci: persepsi pelanggan; bauran pemasaran; kedai kopi

\section{Abstract}

The number of coffee shops in the city of Bandung makes competition between coffee shops even tighter. Therefore, applying the right marketing mix will greatly affect customer interest in choosing a coffee shop. Kopi Janji Jiwa Braga is one of the bestselling coffee shops in Bandung. However, with the establishment of Kopi Kenangan Braga, Kopi Janji Jiwa Braga has a direct competitior. This study aims to determine the comparison of customer perceptions of the marketing mix in Kopi Janji Jiwa Braga and Kopi Kenangan Braga. The marketing mix studied included 7 elements and 29 marketing mix indicators. The method used in this research is descriptive method. The population of this study are customers who have visited Kopi Janji Jiwa Braga and Kopi Kenangan Braga. The sample used was 122 people. Data collection 
techniques used were observation, interviews, and questionnaires. The data analysis technique used is descriptive and the Mann-Whitney test. The results showed that: customer perceptions of the marketing mix of Kopi Janji Jiwa Braga and Kopi Kenangan Braga are positive. Customer perceptions of the 7 elements of the marketing mix of Kopi Jiwa Braga and Kopi Kenangan Braga are positive. Customer perception of the 29 indicators of the marketing mix of Kopi Janji Jiwa Braga and Kopi Kenangan Braga is in agreement, except for the uniqueness and lighting indicators of Kopi Kenangan Braga, which results are quite agreeable. Of the 29 indicators of customer perception of the marketing mix of Kopi Janji Jiwa Braga and Kopi Kenangan Braga, 12 indicators are not different while 17 indicators are different.

Keywords: customer perception; marketing mix; coffee shops

\section{Pendahuluan}

Perkembangan bisnis dewasa ini telah berkembang sangat pesat dan mengalami metamorfosis yang dinamis serta berkesinambungan. Setiap pelaku usaha di setiap kategori bisnis dituntut untuk sigap terhadap setiap perubahan yang terjadi dan menjadikan kepuasan pelanggan sebagai tujuan utama (Kotler \& Armstrong, 2012), tidak terkecuali usaha dalam penyajian makanan dan minuman (food service). Perkembangan indsutri kopi saat ini telah menjadi gaya hidup masyarakat Indonesia. Kini, tradisi meminum kopi tidak hanya terbatas dalam perjamuan tamu ataupun undangan pernikahan. Beberapa aktivitas lain seperti rapat, reuni, kencan ataupun pertemuan bisnis, tidak dapat di pisahkan dari secangkir kopi (www.cikopi.com). Sejak 2013 hingga kini, Indonesia selalu menduduki peringkat 5 besar sebagai negara dengan produksi biji kopi terbesar di dunia dengan produksi berkisar 580.000 ton biji kopi per tahun, dari 1,3 juta hektar area kebun kopi (Harahap, 2015).

Tingginya tingkat permintaan serta meningkatnya produksi kopi di Indonesia dilihat sebagai peluang oleh para pengusaha untuk membuat kedai kopi di berbagai kota di Indonesia. Mengacu pada hasil riset yang dikemukakan oleh Toffin dalam detik finance, jumlah kedai kopi di Indonesia pada Agustus 2019 mencapai lebih dari 2.950 gerai. Angka itu ternyata meningkat sekitar tiga kali lipat atau bertambah 1950 dari tahun 2016 yang hanya 1000 gerai. Dilansir dari tirto.id, Andi K. Yuwono melakukan survei dan menyatakan ada sekitar 600 kedai kopi di Kota Bandung pada Juli 2019. Hal tersebut menandakan bahwa lebih dari $20 \%$ kedai kopi yang ada di Indonesia berada di Kota Bandung.

Semakin banyaknya kedai kopi, menimbulkan persaingan dalam industri kopi menjadi semakin ketat. Situasi ini menuntut perusahaan untuk terus memberikan nilai yang positif agar konsumen tidak beralih kepada kompetitor. Hal ini berlaku pula bagi Kopi Janji Jiwa yang terletak di Jalan Braga Kota Bandung. Hingga Oktober tahun 2019, Kopi Janji Jiwa Braga merupakan salah satu kedai kopi terlaris versi Grab (bagian kiri gambar) dan Best Seller versi GoJek (bagian kanan) di Kota Bandung. Rating yang dimiliki juga cukup baik yaitu 4.8/5 untuk Grabfood dan 4.7/5 untuk GoFood. Sehingga dapat dikatakan bahwa Kopi Janji Jiwa Braga merupakan salah satu kedai kopi yang 
paling laris dibeli oleh masyarakat Kota Bandung saat ini. Namun, seiring berjalannya waktu. Dikhawatirkan para pembeli yang telah membeli kopi di Kopi Janji Jiwa Braga mulai beralih ke kompetitor karena banyaknya kedai kopi lain yang bermunculan dengan menawarkan berbagai kelebihan seperti harga yang lebih murah, promosi yang lebih besar, serta tempat yang lebih menarik.

Penelitian ini urgent karena penjualan kopi janji jiwa menurun ketika muncul pesaing baru yaitu kopi janji jiwa. Apabila dibiarkan terus menerus, maka tentu akan memberikan dampak yang negatif bagi outlet janji jiwa tersebut. Hal ini tentu akan menimbulkan rasa khawatir bagi kopi Janji Jiwa Braga, bahkan pada awal tahun 2020 Kopi Kenangan masuk dalam daftar kopi terlaris versi GoFood dan GrabFood. Disamping itu, observasi serta wawancara awal dilakukan kepada 2 pegawai Kopi Janji Jiwa Braga. Kedua pegawai tersebut menyebutkan bahwa mereka melihat ada beberapa pelanggan Kopi Janji Jiwa Braga yang biasanya membeli Kopi Janji Jiwa kini beralih membeli Kopi Kenangan. Oleh karena itu, penelitian ini dilakukan untuk membandingkan persepsi pelanggan terhadap bauran pemasaran dari kedua kedai kopi tersebut, sehingga pada akhirnya penulis dapat memberi masukan kepada kopi janji jiwa untuk meningkatkan aspek" pemasaran yang dirasa kurang.

Kopi Janji Jiwa Braga telah menerapkan beberapa cara untuk menanggulanginya. Salah satunya adalah dengan meningkatkan beberapa aspek di bidang bauran pemasaran. Penerapan bauran pemasaran yang tepat akan membuat perusahaan tetap kuat menghadapi persaingan. Beberapa aspek bauran pemasaran yang ditingkatkan seperti melakukan perbaikan dan penambahan speaker musik, renovasi interior, penambahan dan perbaikan property, menambah spot charging, menambah menu dan melakukan diskon lebih besar dari pesaing (Handika \& Darma, 2018). Bahkan saat ini diskon yang diberikan Kopi Janji Jiwa melalui media online GrabFood mencapai 50\%. Diskon ini tentu cukup besar mengingat diskon yang diberikan Kopi Kenangan di platform yang sama hanya sebesar 35\%. Namun hal ini dirasa kurang efektif, meski penjualan meningkat tetapi peningkatan penjualan tidak seperti yang diharapkan. Bahkan pendapatan tidak berbeda secara signifikan dengan sebelum dilakukan upaya tersebut. Beberapa pelanggan yang ditanya seputar diskon tersebut, mengaku bahwa sebenarnya mereka tertarik dengan diskon tersebut, hanya saja karena penyajiannya yang kurang cepat dan produk kurang menarik membuat mereka lebih memilih Kopi Kenangan dengan diskon yang lebih kecil namun penyajiannya lebih cepat dan menarik.

Hal ini didukung pula oleh teori, bahwa salah satu cara utuk menambah nilai bagi pelanggan adalah melalui gaya dan desain produk yang khas. Konsep desain lebih luas dibandingkan gaya. Desain yang baik dapat memberikan kontribusi dalam hal kegunaan produk dan juga penampilannya (Nendi, 2016). Gaya dan desain yang baik dapat menarik perhatian, meningkatkan kinerja produk, memotong biaya produksi dan memberikan keunggulan bersaing di pasar sasaran. Apabila suatu produk memiliki atribut atau sifatsifat yang sesuai dengan apa yang diharapkan oleh pembelinya maka produk tersebut akan dianggap cocok dan akan menjadi dasar keputusan pembelian oleh konsumen (Kotler \& Keller, 2016). Keputusan Pembelian pada akhirnya akan membuat tujuan 
perusahaan terpenuhi dalam hal memperoleh laba/ keuntungan (Asman \& Apriliani, 2020). Menurut (Nugroho, 2017) proses pengambilan keputusan terbatas terjadi apabila konsumen atau pengambil keputusan terlebih dulu mengenali masalah produk.

Hal ini juga sejalan dengan apa yang dikatakan (Qomaro, 2018) yang menyebutkan bahwa persepsi konsumen mempengaruhi keputusan pembelian. Hal ini berlaku juga untuk persepsi konsumen terhadap bauran pemasaran. Ketika persepsi konsumen terkait bauran pemasaran membaik, maka penjualan akan otomatis meningkat begitupun sebaliknya. Kurangnya penjualan Kopi Janji Jiwa Braga seperti yang dijelaskan pada paragraf sebelumnya, mengindikasikan bahwa persepsi pelanggan terhadap bauran pemasaran Kopi janji Jiwa Braga sudah berubah ke arah yang kurang baik. Bahkan cenderung tidak lebih baik dalam beberapa aspek jika dibandingkan dengan kompetitornya yaitu Kopi Kenangan Braga.

Hingga saat penelitian ini dilakukan, belum ditemukan penelitian terdahulu yang pernah membandingkan kedua kedai kopi tersebut, yakni Kopi Janji Jiwa Braga dan Kopi Kenangan Braga. Di sisi lain, kedua kedai kopi tersebut merupakan pendatang baru di industri kuliner Indonesia. Dengan demikian, penelitian ini merupakan penelitian pertama yang membandingkan antara kedai Kopi Janji Jiwa Braga dan Kopi Kenangan Braga.

Tujuan penelitian ini adalah untuk mengetahui terdapat tidaknya perbedaan antara persepsi pelanggan terhadap bauran pemasaran Kopi Janji Jiwa Braga dan Kopi Kenangan Braga.

\section{Metode Penelitian}

Metode yang digunakan dalam penelitian ini adalah metode deskriptif. Metode deskriptif adalah metode yang digunakan untuk mencari unsur-unsur, ciri-ciri, sifat-sifat suatu fenomena. Metode ini dimulai dengan mengumpulkan data, menganalisa data, dan menginterpretasikannya (Suryana, 2010). Metode deskriptif digunakan untuk mengumpulkan data yang menjelaskan karakteristik dari orang, kejadian, atau situasi (Sekaran \& Bougie, 2013).

Teknik pengumpulan data dalam penelitian ini adalah sebagai berikut:

\section{Observasi}

Merupakan teknik pengumpulan data dengan cara melakukan pengamatan secara langsung mengenai objek yang sedang diteliti. Pada penelitian ini dilakukan observasi terhadap kopi Janji Jiwa Braga dan Kopi Kenangan Braga.

2. Wawancara

Merupakan teknik pengumpulan data yang dilakukan dengan menanyakan secara langsung kepada pihak-pihak yang dapat memberikan informasi terkait objek yang diteliti mengenai suatu fenomena tertentu (Sudaryono, 2018).

3. Kuesioner

Kuesioner merupakan alat pengumpulan data yang disebut dengan angket yang berisi sejumlah pertanyaan yang harus dijawab atau direspon oleh responden (Sudaryono, 2018). Kuesioner disebar dengan tujuan untuk mendapatkan informasi dari responden dan diolah menjadi data yang kemudian akan dianalisis untuk menguji hipotesis. 
Subjek pada penelitian ini diklarifikasi berdasarkan demografi. Kriteria yang digunakan untuk melakukan klasifikasi terbagi atas jenis kelamin, usia, frekuensi pembelian dan pengeluaran untuk membeli kopi di kedai kopi per bulan. Selanjutnya, subjek akan dikonfirmasi terkait persayaratan sebagai responden. Setelah itu subjek akan mengisi daftar pertanyaan. Subjek hanya dapat memilih rating skala likert dari skala satu sampai lima. Semakin tinggi skala yang dipilih, berarti semakin setuju dengan pernyataan pada butir kusioner (Sudaryono, 2018).

4. Studi literatur

Merupakan teknik pengumpulan data dengan cara mencari teori-teori, data dan informasi yang berhubungan dengan permasalahan dan variabel yang diteliti. Studi literatur yang dilakukan yaitu dengan mempelajari berbagai jurnal, artikel ilmiah, website, buku dan penelitian terdahulu yang dijadikan referensi serta sumber informasi pada penelitian ini.

Penelitian ini dilakukan di Kopi Janji Jiwa Braga dan Kopi Kenangan yang berada di pusat perbelanjaan Braga City Walk, yang beralamat di Jalan Braga Nomor 99-101 Bandung, Jawa Barat. Penelitian ini menggunakan teknik purposive sampling, yaitu memilih subjek spesifik yang dapat memberikan informasi yang diinginkan, dikarenakan hanya mereka yang punya informasi tersebut atau mereka memenuhi kriteria dari peneliti. Purposive sampling dibagi menjadi dua yaitu judgmenet and quota (Nurchasanah, Yunilma, \& Resti, 2020). Penelitian ini menggunakan purposive judgement sampling karena menggunakan tempat dan subjek yang paling cocok untuk memberikan informasi. Teknik ini digunakan ketika jumlah pemilik informasi yang dicari terbatas. Informasi diperoleh dari orang-orang spesifik yang mempunyai fakta dan dapat memberikan informasi yang dicari (Sekaran \& Bougie, 2013). Jumlah responden dalam penelitian ini berjumlah 122 orang.

Langkah-langkah yang dilakukan dalam pengolahan data yaitu sebagai berikut:

1. Uji Validitas dan Uji Reliabilitas

Alat ukur dan hasil pengukuran yang digunakan pada penelitian harus diuji kebenarannya. Pengujian untuk alat ukur disebut uji validatas sedangkan pengujian untuk hasil pengukuran dinamakan reliabilitas. Validitas adalah sejauh mana ketepatan dan kecermatan suatu alat ukur dalam melakukan fungsi ukurnya atau suatu konsep yang berkaitan dengan sejauh mana tes telah mengukur apa yang seharusnya diukur (Sudaryono, 2018). Dalam penelitian ini, uji validitas menggunakan corrected item total correlation dari masing-masing item pertanyaan. Jika nilai korelasinya $\geq 0,3$ maka item pertanyaan tersebut dianggal valid (Sugiyono, 2015).

Reliabilitas adalah suatu cara untuk mengukur suatu kuesioner yang merupakan indikator dari variabel. Suatu hasil pengukuran hanya dapat dipercaya apabila dalam beberapa kali pelaksanaan pengukuran terhadap kelompok subjek yang sama, diperoleh hasil pengukuran yang relatif sama, selama aspek yang diukur dalam diri subjek memang belum berubah (Sudaryono, 2018). Variabel yang diteliti dinyatakan reliabel apabila cronbach's alpha adalah di atas 0,6. Apabila nilai cronbach alpha di bawah 0,6 maka variabel tersebut dinyatakan tidak reliabel (Sekaran \& Bougie, 2013). 


\section{Analisis Kualitatif Deskriptif}

Menganalisis, mengeksplor, menggambarkan, dan meringkas berbagai fenomena yang tidak dapat dikuantifikasikan dan bersifat deskriptif, dari berbagai data yang dikumpulkan berkenaan dengan masalah yang diteliti yang terjadi di lapangan (Aan \& Djam'an, 2011). Dalam penelitian ini, analisis ini dilakukan untuk mengetahui bagaimana persepsi pelanggan terhadap bauran pemasaran serta perbandingannya di Kopi Janji Jiwa Braga dan Kopi Kenangan Braga, maka data yang terkumpul melalui kuesioner selanjutnya diolah dengan cara menjumlah setiap jawaban kuesioner yang telah diisi oleh responden sesuai nilai yang diberikan. Lalu jawaban tersebut dibagi dengan banyaknya jumlah responden (pelanggan) yaitu 122 orang untuk mendapatkan score rata-rata hitung. Skor rata-rata hitung jawaban dari responden atas pertanyaan dalam kuesioner disajikan dalam bentuk tabel yang kemudian dianalisis secara deskriptif kualitatif. Kategori skor rata-rata hitung per indikator dan per dimensi yang diperoleh yaitu sebagai berikut:

\section{Tabel 1}

Kategori Skor Rata-Rata Hitung per Indikator

\begin{tabular}{cc}
\hline Rata-Rata Hitung & Interpretasi \\
\hline $4,2 \leq \bar{x} \leq 5.0$ & Sangat Setuju dengan pernyataan \\
\hline $3,4 \leq \bar{x} \leq 4,2$ & Setuju dengan pernyataan \\
\hline $2,6 \leq \bar{x} \leq 3,4$ & Cukup setuju dengan pernyataan \\
\hline $1,8 \leq \bar{x} \leq 2,6$ & Tidak Setuju dengan pernyataan \\
\hline $1,0 \leq \bar{x} \leq 1,8$ & Sangat tidak setuju dengan pernyataan \\
\hline & Sumber: Penulis
\end{tabular}

Tabel 2

Kategori Skor Rata-Rata Hitung per Dimensi

\begin{tabular}{cc}
\hline Rata-Rata Hitung & Interpretasi \\
\hline $4,2 \leq \bar{x} \leq 5.0$ & Sangat Positif \\
\hline $3,4 \leq \bar{x} \leq 4,2$ & Positif \\
\hline $2,6 \leq \bar{x} \leq 3,4$ & Cukup Positif \\
\hline $1,8 \leq \bar{x} \leq 2,6$ & Negatif \\
\hline $1,0 \leq \bar{x} \leq 1,8$ & Sangat Negatif \\
\hline
\end{tabular}

Sumber: Penulis

\section{Uji Mann-Whitney}

Guna menemukan ada atau tidaknya perbedaan persepsi pelanggan terhadap bauran pemasaran Kopi Janji Jiwa Braga dan Kopi Kenangan Braga, data yang terkumpul melalui kuesioner diolah dan dianalisis dengan metode uji beda nonparametrik Mann-Whitney. Analisis tersebut dilakukan dengan bantuan program SPSS 23. Hipotesis yang diuji dalam penelitian adalah:

$\mathrm{H}_{\mathrm{a}}=$ Terdapat perbedaan persepsi pelanggan terhadap bauran Pemasaran Kopi Janji Jiwa Braga dan Kopi Kenangan Braga.

Sedangkan kriteria uji hipotesis adalah sebagai berikut (Sugiyono, 2017):

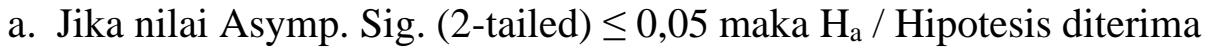




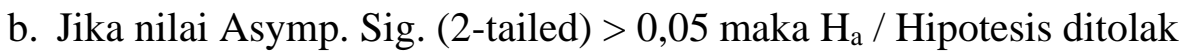

Uji tersebut dilakukan pada 7 Dimensi/ elemen bauran pemasaran dan 29 indikator bauran pemasaran.

\section{Hasil dan Pembahasan}

Hasil uji validitas dalam penelitian ini menunjukkan bahwa setiap dimensi/ elemen bauran pemasaran pada Kopi Janji jiwa Braga dan Kopi Kenangan Braga menghasilkan cronbach's Alpha lebih dari 0,6. Dengan demikian, setiap indikator pertanyaan dalam penelitian ini dianggap valid. Hasil uji reliabilitas menunjukkan bahwa setiap indikator pertanyaan pada Kopi Janji Jiwa Braga dan Kopi Kenangan Braga memiliki nilai lebih dari 0,3. Oleh karena itu setiap indikator pertanyaan tersebut dianggap reliabel.

Bawah ini merupakan hasil analisis data berdasarkan persepsi pelanggan terhadap bauran pemasaran Kopi Janji Jiwa Braga dan Kopi Kenangan Braga.

Tabel 3

Hasil Analisis

\begin{tabular}{lccc}
\hline \multirow{2}{*}{ Bauran Pemasaran } & \multicolumn{2}{c}{ Rata-Rata Persepsi Pelanggan } & \multirow{2}{*}{ Hasil Uji Beda } \\
\cline { 2 - 3 } & Kopi Janji Jiwa & Kopi Kenangan & \\
\hline Product & Positif & Positif & Berbeda \\
\hline Price & Positif & Positif & Sama \\
\hline Place & Positif & Positif & Sama \\
\hline Promotion & Positif & Positif & Berbeda \\
\hline People & Positif & Positif & Sama \\
\hline Process & Positif & Positif & Berbeda \\
\hline Physical Evidence & Positif & Positif & berbeda \\
\hline Bauran Pemasaran & Positif & Positif & sama \\
\hline
\end{tabular}

Sumber: Penelitian 2021

Berdasarkan hasil penelitian, didapatkan hasil bahwa bauran pemasaran Kopi Janji Jiwa Braga dan Kopi Kenangan Braga sama-sama menghasilkan nilai positif. Persepsi pelanggan terhadap setiap elemen bauran pemasaran yang diterapkan oleh Kopi Janji Jiwa Braga adalah positif. Demikian juga dengan Kopi Kenangan, persepsi pelanggan terhadap setiap bauran pemasaran yang diterapkan oleh Kopi Kenangan Braga adalah positif. Persepsi pelanggan untuk setiap indikator dari 29 indikator bauran pemasaran yang ada pada Kopi Janji Jiwa Braga dan Kopi Kenangan Braga adalah setuju, kecuali 2 indikator yaitu keunikan minuman dan pencahayaan pada Kopi Kenangan Braga hanya memperoleh hasil cukup setuju (Purwanti, 2013).

Meski secara keseluruhan bauran pemasaran Kopi Janji Jiwa Braga dan Kopi Kenangan Braga sama-sama memiliki nilai positif, namun masing-masing kedai kopi, baik Kopi Janji Jiwa Braga maupun Kopi Kenangan Braga memiliki keunggulannya masing-masing menyangkut elemen bauran pemasaran menurut persepsi pelanggan. Kopi Janji Jiwa Braga unggul dalam elemen product, price dan promotion. Dari segi product Kopi Janji Jiwa Braga lebih unggul dari Kopi Kenangan Braga. Hal ini karena Kopi Janji Jiwa Braga memberikan kualitas rasa, variasi, inovasi serta keunikan yang lebih baik 
dibandingkan dengan Kopi Kenangan Braga. Menyangkut elemen price Kopi Janji Jiwa Braga lebih unggul jika dibandingkan dengan Kopi Kenangan Braga. Hal ini dikarenakan Kopi Janji Jiwa Braga dan Kopi Kenangan Braga memiliki harga minuman yang hampir serupa meskipun Kopi Janji Jiwa sedikit lebih murah pada beberapa varian minumannya. Sedangkan menyangkut promotion, pelanggan menganggap Kopi Janji Jiwa Braga lebih unggul ketimbang Kopi Kenangan Braga. Penyebab utama keunggulan Kopi Janji Jiwa Braga ketimbang Kopi Kenangan Braga adalah lebih besarnya diskon dan insentif yang diberikan.

Kopi Kenangan Braga unggul dari elemen people, physical evidence dan process. Keunggulan elemen people Kopi Kenangan Braga terjadi karena pelayan Kopi Kenangan Braga yang dinilai lebih rapih dan menarik serta penyampaian info yang lebih mudah dipahami oleh pelanggan dibandingkan dengan Kopi Janji Jiwa Braga. Keunggulan elemen process Kopi Kenangan Braga terjadi karena Kopi Kenangan Braga memberikan penyajian minuman yang lebih cepat dan lebih menarik dibandingkan dengan Kopi Janji Jiwa Braga. Keunggulan elemen physical evidence Kopi Kenangan Braga dibandingkan dengan Kopi Janji Jiwa Braga terjadi karena suasana di kedai Kopi Kenangan Braga lebih nyaman ditambah dengan musik yang sesuai dengan suasana yang menambah kenyamanan konsumen. Menyangkut elemen place Kopi Janji Jiwa Braga dan Kopi Kenangan Braga mendapatkan hasil rata-rata yang identik. Hal ini karena Kopi Janji Jiwa Braga memiliki lokasi yang tepat bersebehalan serta sama-sama telah mengakomodir ketersediaan pembelian secara online.

Analisis persepsi pelanggan terhadap bauran pemasaran menggunakan uji beda memberi hasil bahwa elemen bauran pemasaran product, promotion, process, dan physical evidence berbeda antara Kopi Janji Jiwa Braga dan Kopi kenangan Braga. Sedangkan elemen bauran price, place, people memberikan hasilnya tidak berbeda (sama) antara Kopi janji Jiwa Braga dan Kopi Kenangan Braga. Hal ini juga berlaku bagi bauran pemasaran secara umum, dimana hasilnya menunjukkan bahwa menurut persepsi pelanggan Kopi Janji Jiwa dan Kopi Kenangan Braga memiliki bauran pemasaran yang tidak berbeda (sama).

Elemen product Kopi Janji Jiwa Braga lebih fokus pada pengembangan inovasi serta keunikan minuman yang original. Sedangkan Kopi Kenangan Braga cenderung memberikan inovasi dengan mengikuti kompetitor. Pada elemen price Kopi Janji Jiwa Braga dan Kopi Kenangan Braga memiliki harga yang relatif bersaing dengan metode pembayaran yang hampir serupa. Pada elemen promotion Kopi Janji Jiwa Braga lebih fokus memberikan diskon yang besar sedangkan Kopi Kenangan Braga memberikan diskon yang relatif lebih kecil namun tetap dengan iklan yang seimbang. Pada elemen place, Kopi Janji Jiwa dan Kopi Kenangan Braga hampir indentik karena posisinya yang terletak tepat bersebelahan satu dengan yang lainnya. Pada elemen people baik Kopi Janji Jiwa Braga maupun Kopi Kenangan Braga sama-sama telah memiliki standar yang baik dalam melayani konsumen. Pada elemen process Kopi Kenangan Braga menggunakan teknik dengan peralatan yang lebih mutakhir, sehingga lebih cepat dalam penyajiannya sedangkan Kopi Janji Jiwa Braga menggunakan teknik dan perlatan yang lebih mekanik 
dan sederhana. Dari segi physical evidence Kopi Janji Jiwa Braga lebih terang namun terkesan kurang nyaman karena musik yang tidak sesuai dan pelayanan kebersihan yang lebih lambat sedangkan Kopi Kenangan Braga memiliki musik yang sesuai dengan pelayanan kebersihan yang baik sehingga lebih nyaman meskipun kurang dalam pencahayaan.

\section{Kesimpulan}

Berdasarkan hasil penelitian tentang perbandingan persepsi pelanggan terhadap bauran pemasaran, Kopi Janji Jiwa Braga dan Kopi Kenangan Braga, maka diambil kesimpulan bahwa secara keseluruhan persepsi pelanggan terhadap bauran pemasaran Kopi Janji Jiwa Braga adalah positif. Persepsi pelanggan untuk setiap elemen bauran pemasaran (product, price, place, promotion, people, process, dan physical evidence) adalah positif. Persepsi pelanggan untuk setiap indikator dari 29 indikator bauran pemasaran yang ada adalah setuju. Secara keseluruhan persepsi pelanggan terhadap bauran pemasaran Kopi Kenangan Braga adalah positif. Persepsi pelanggan untuk setiap elemen bauran pemasaran (product, price, place, promotion, people, process, dan physical evidence) adalah positif. Persepsi pelanggan untuk setiap indikator dari 29 indikator bauran pemasaran yang ada adalah setuju kecuali 2 indikator yaitu keunikan minuman dan pencahayaan hanya memperoleh cukup setuju. Perbandingan nilai rata-rata menurut persepsi pelanggan terhadap bauran pemasaran Kopi Janji Jiwa Braga dan Kopi Kenangan Braga menghasilkan perbedaan dengan masing-masing memiliki keunggulan dan kekuarangan di setiap indikator ataupun elemen bauran pemasaran. Kopi Janji Jiwa Braga unggul 13 indikator bauran pemasaran sedangkan Kopi kenangan unggul 16 indikator. Perelemen bauran pemasaran, Kopi Janji Jiwa Braga unggul di 3 elemen yaitu product, price, dan promotion sedangkan Kopi Kenangan unggul di elemen people, process, dan physical evidence. Pada elemen place, Kopi Janji Jiwa Braga dan Kopi Kenangan Braga menghasilkan nilai yang identik. Secara umum bauran pemasaran, menurut persepsi pelanggan Kopi Kenangan Braga sedikit lebih unggul dari Kopi Janji Jiwa. Meski demikian, seluruh indikator maupun elemen bauran pemasaran menghasilkan persepsi yang positif. Termasuk juga bauran pemasaran secara umum. Secara statistik persepsi pelanggan terhadap bauran pemasaran Kopi Janji Jiwa Braga dan Kopi Kenangan Braga tidak memiliki perbedaan (sama). Persepsi pelanggan terhadap elemen bauran pemasaran product, promotion, process, dan physical evidence pada Kopi Janji Jiwa Braga dan Kopi Kenangan Braga memiliki perbedaan. Sedangkan persepsi pelanggan terhadap elemen bauran pemasaran price, place dan people pada Kopi Janji Jiwa Braga dan Kopi Kenangan Braga tidak terdapat perbedaan (sama), dari 29 indikator pertanyaan menyangkut persepsi pelanggan terhadap bauran pemasaran, 12 indikator terdapat perbedaan sedangkan 17 indikator tidak terdapat perbedaan (sama). 


\section{BIBLIOGRAFI}

Aan, Komariah, \& Djam'an, Satori. (2011). Metode Penelitian Kualitatif. Bandung: Alfabeta. Google Scholar

Asman, Nasir, \& Apriliani, Nina. (2020). Pengaruh Harga Dan Promosi Terhadap Keputusan Pembelian Sim Card Axis. Syntax Literate; Jurnal Ilmiah Indonesia, 5(7), 398-413. Google Scholar

Handika, Made Resta, \& Darma, Gede Sri. (2018). Strategi Pemasaran Bisnis Kuliner Menggunakan Influencer Melalui Media Sosial Instagram. Jurnal Manajemen Bisnis, 15(2), 192-203. Google Scholar

Harahap, Emilia. (2015). Produsen Kopi Luwak Kini Harus Jamin Luwaknya Sejahtera. Bandung. Diakses dari https://finance.detik.com/berita-ekonomi-bisnis/d2965337/produsen-kopi-luwak-kini-harus-jamin-luwaknya-sejahtera Google Scholar

Kotler, Philip, \& Armstrong, Gary. (2012). Principles Of Marketing 14th Edition. New Jearsey: Pearson Education Inc, 67. Google Scholar

Kotler, Philip, \& Keller, Kevin Lane. (2016). Marketing Management (15th Global Ed.). England: Pearson. Google Scholar

Nendi, Ikhsan. (2016). Implementasi Strategi Pemasaran Kredit Kepemilikan Rumah (KPR) Di Bank Muamalat Cabang Cirebon. Syntax Literate; Jurnal Ilmiah Indonesia, 1(1), 80-91. Google Scholar

Nugroho, Ari. (2017). Strategi Marketing Mix, Loyalitas Konsumen, Dan Efektifitas Kerja Terhadap Keputusan Pembelian La Lights. Syntax Literate; Jurnal Ilmiah Indonesia, 2(7), 26-39. Google Scholar

Nurchasanah, Julia Permatasari, Yunilma, Yunilma, \& Resti, Yulistia Muslim. (2020). Analisis Pengaruh Fraud Triangle Dalam Mendeteksi Kecurangan Laporan Keuangan (Studi Empiris Pada Perusahaan Sub Sektor Infrastruktur, Utilitas Dan Transportasi Yang Terdaftar Di Bursa Efek Indonesia (BEI) Periode 2015-2019) Nurchasanah Julia Permatasari1. Diploma thesis, Universitas Bung Hatta. Google Scholar

Purwanti, Endang. (2013). Pengaruh Karakteristik Wirausaha, Modal Usaha, Strategi Pemasaran Terhadap Perkembangan UMKM Di Desa Dayaan Dan Kalilondo Salatiga. Among Makarti, 5(1). 13-28. Google Scholar

Qomaro, Galuh Widitya. (2018). Sertifikasi Halal Dalam Persepsi Konsumen Pada Produk Pangan Di Kabupaten Bangkalan. KABILAH: Journal Of Social Community, 3(2), 241-251. Google Scholar

Sekaran, Uma, \& Bougie, Roger. (2013). Research Methods For Business. Edisi Enam. 
Analisis Perbandingan Persepsi Pelanggan terhadap Bauran Pemasaran Kopi Janji Jiwa dan Kopi Kenangan

Jakarta: Salemba Empat. Google Scholar

Sudaryono. (2018). Metodologi Penelitian. Jakarta: Rajawali Press. Google Scholar

Sugiyono. (2015). Metode Penelitian Dan Pengembangan Pendekatan Kualitatif, Kuantitatif, Dan R\&D. Bandung: CV Alfabeta. Google Scholar

Sugiyono. (2017). Metode Penelitian Kuantitatif. Bandung: CV Alfabeta. Google Scholar

Suryana, M. S. (2010). Metodologi Penelitan Model Prakatis Penelitian Kuantitatif Dan Kualitatif. Jakarta: Universits Pendidikan Indonsia. Google Scholar

\section{Copyright holder:}

Ivan Christian, Jesslyn Kartawidjaja (2021)

First publication right:

Syntax Literate: Jurnal Ilmiah Indonesia

This article is licensed under: 